\title{
Synthesis, structural characterization and biological activity of a trinuclear zinc(II) complex: DNA interaction study and antimicrobial activity
}

\author{
BHASKAR BISWAS $^{\mathrm{a}, *}$, NIRANJAN KOLE ${ }^{\mathrm{a}}$, MOUMITA PATRA $^{\mathrm{b}}$, SHAMPA DUTTA ${ }^{\mathrm{c}}$ \\ and MOUSUMI GANGULYc \\ ${ }^{a}$ Department of Chemistry, ${ }^{b}$ Department of Physics, Raghunathpur College, Purulia 723 133, India \\ ${ }^{c}$ Department of Environmental Science, The University of Burdwan, Burdwan 713 104, India \\ e-mail: mr.bbiswas@rediffmail.com
}

MS received 9 April 2013; revised 6 September 2013; accepted 11 September 2013

\begin{abstract}
A trinuclear zinc(II) complex $\left[\mathrm{Zn}_{3} \mathbf{L}_{2}\left(\mu-\mathrm{O}_{2} \mathrm{CCH}_{3}\right)_{2}\left(\mathrm{H}_{2} \mathrm{O}\right)_{2}\right] \cdot \mathrm{H}_{2} \mathrm{O} \cdot 2 \mathrm{CH}_{3} \mathrm{OH}(\mathbf{1})$ was synthesized from an in situ reaction between zinc acetate and a Schiff base ligand $\left(\mathrm{H}_{2} \mathbf{L}=2\right.$-( (2-hydroxyphenylimino) methyl)-6-methoxyphenol). The ligand was prepared by $(1: 1)$ condensation of ortho-vanillin and orthoaminophenol. The ligand and zinc(II) complex were characterized by elemental analysis, Fourier Transform Infrared (FTIR), ${ }^{1} \mathrm{H}-$ Nuclear Magnetic Resonance (NMR), UV-Vis spectroscopy, Powder X-ray Diffraction (PXRD) and thermogravimetric analysis. 1 crystallizes in P-1 space group with $a=11.9241(3) \AA, b=$ $12.19746 \AA, c=20.47784 \AA$ with unit cell volume is $2674.440(\AA)^{3}$. Binding property of the complex with calf thymus DNA (CT-DNA) has been investigated using absorption and emission studies. Thermal melting and viscosity experiments were further performed to determine the mode of binding of 1 with CT-DNA. Spectroscopic and viscosity investigations revealed an intercalative binding mode of 1 with CT-DNA. The ligand and its zinc complex were screened for their biological activity against bacterial species and fungi. Activity data show that the metal complex has more antibacterial and antifungal activity than the parent Schiff base ligand and against those bacterial or fungi species.
\end{abstract}

Keywords. Zinc(II); Schiff base; DNA binding study; antimicrobial investigation.

\section{Introduction}

The discovery and development of antibiotics are among the most powerful and successful achievements of modern science and technology for the control of infectious diseases. Metal-based drugs represent a novel group of antibacterial and antifungal agents with potential applications for the control of bacterial and fungal infections. ${ }^{1-3}$ Transition metal complexes have powerful antimicrobial activities and are already in common day-to-day use in medicinal field such as silver bandages for treatment of burns, zinc antiseptic creams, bismuth drugs for the treatment of ulcers and metal clusters as anti-HIV agents. ${ }^{4-6}$

Transition metal complexes that can bind the DNA under physiological conditions are of current interest in the development of metal-based anticancer agents. ${ }^{7-9}$ Numerous biological experiments have demonstrated

*For correspondence that DNA is the primary intracellular target of anticancer drugs; interaction between small molecules and DNA can cause damage in cancer cells, blocking the division and resulting in cell death. ${ }^{9}$ This inspires synthetic chemists to search for new metal complexes for bioactive compounds.

The synthesis of a new ligand is the most important step in the development of metal complexes regarding its unique properties and novel reactivity. Schiff bases are very attractive class of ligands because of their ease of preparation and simple modification of both stearic and electronic properties. Schiff bases are compounds with imine functional groups and were first prepared by Hugo Schiff in $1864 .{ }^{10}$ The chemistry of Schiff base and its zinc complexes have occupied a place of considerable importance as they have a variety of applications including biological, clinical, analytical and industrial, in addition to their important roles in catalysis and organic synthesis. ${ }^{11-13}$ In the present study, we report the results on the synthesis, spectroscopic and structural characterization, DNA-binding property and antimicrobial activities of a $\mathrm{Zn}$ (II) Schiff base complex. 


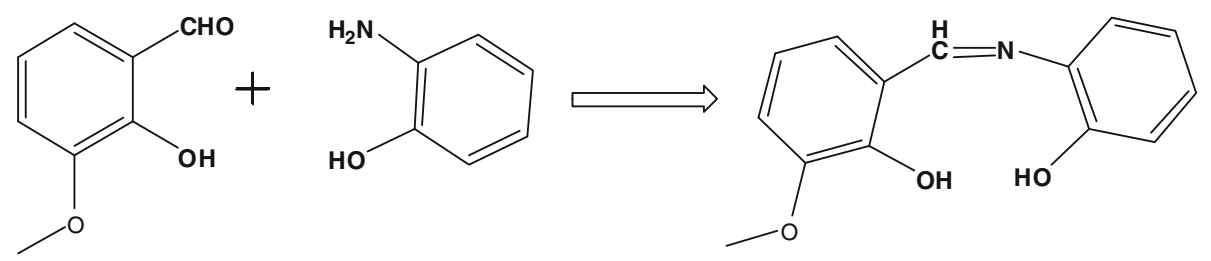

Scheme 1. Synthetic route for the ligand.

\section{Experimental}

\subsection{Preparation of the complex}

2.1a Chemicals, solvents and starting materials: High purity $O$-vanillin (E Merck, India), $O$-aminophenol (E Merck, India), zinc(II) acetate and all other solvents were purchased from the respective concerns and used as received. The calf thymus (CT) DNA and ethidium bromide (EB) were obtained from Sigma Aldrich Corporation (St. Louis, MO, USA). DNA concentrations were determined spectrophotometrically using the reported data for a molar absorption coefficient of $6600 \mathrm{M}^{-1} \mathrm{~cm}^{-1}$ at $260 \mathrm{~nm}$. For viscosity studies, the DNA sample was dissolved in the experimental buffer and sonicated to uniform size of about $280 \pm 50$ base pairs using a Labsonic 2000 sonicator (B Braun, Germany) using a needle probe of $4 \mathrm{~mm}$ diameter. The sonicated DNA sample was dialysed several times against the experimental buffer under sterile conditions in a cold room and stored at $5^{\circ} \mathrm{C}$ till use. All other chemicals and solvents were of analytical grade and were used as received without further purification.

2.1b Preparation of $\mathrm{H}_{2} \mathbf{L}$ and 1 : The Schiff base $\mathrm{H}_{2} \mathbf{L}$ was prepared following a reported method ${ }^{14}$ with a little modification. The details are given below:

$O$-aminophenol $(0.1092 \mathrm{~g}, 1 \mathrm{mmol})$ was refluxed with $O$-vanillin $(0.1523 \mathrm{~g}, 1 \mathrm{mmol})$ in $20 \mathrm{ml}$ dehydrated alcohol. After $10 \mathrm{~h}$, the reaction solution was kept in open atmosphere and red coloured crystalline compound was separated out from solution, which was dried and stored in vaccuo over $\mathrm{CaCl}_{2}$ for subsequent use. Yield $0.213 \mathrm{~g}(87.2 \%)$. Anal calc. for $\mathrm{C}_{14} \mathrm{H}_{13} \mathrm{NO}_{3}$ $\left(\mathrm{H}_{2} \mathbf{L}\right)$ : C, 69.12; H, 5.39; N, 5.76; Found: C, 69.03; H, 5.30; N, 5.68 IR ( $\mathrm{KBr}$ pellet, $\left.\mathrm{cm}^{-1}\right): 3365(\mathrm{~s})\left(\mathrm{v}_{\mathrm{OH}}\right)$, 1618 (s), 1595 (s) ( $\left.\mathrm{v}_{\mathrm{C}=\mathrm{N}}\right), 1509$ (s), 1462 (s), 1333 (s), $1245(\mathrm{~s})\left(\mathrm{v}_{\mathrm{OAr}}\right)$; UV-Vis $\left(\lambda_{\max }, \mathrm{nm}\right): 233,275,347,461$; ${ }^{1} \mathrm{H}$ NMR $\left(\delta \mathrm{ppm}, 400 \mathrm{Mz}, \mathrm{DMSO}-d^{6}\right) \delta=12.58(\mathrm{~s}$, $1 \mathrm{H}), 8.70$ (s, 1H), 7.26-6.90 (Ar-H, 7H), 5.94 (s, 1H), 3.93 (s, 3H) ppm (scheme 1).

A methanolic solution $\left(5 \mathrm{~cm}^{3}\right)$ of $\mathrm{H}_{2} \mathbf{L}(0.244 \mathrm{~g}, 1 \mathrm{mmol})$ was added dropwise to a solution of $\mathrm{Zn}(\mathrm{OAc})_{2} \cdot 2 \mathrm{H}_{2} \mathrm{O}$ $(0.219 \mathrm{~g}, 1 \mathrm{mmol})$ in the same solvent $\left(10 \mathrm{~cm}^{3}\right)$. The yellow solution was filtered and the supernatant liquid was kept in air for slow evaporation. Yield: $0.183 \mathrm{~g}$ (83\% based on metal salt). Anal. Calc. for $\mathrm{C}_{34} \mathrm{H}_{42} \mathrm{~N}_{2}$ $\mathrm{O}_{15} \mathrm{Zn}_{3}(\mathbf{1})$ : C, 44.63; H, 4.63; N, 3.06. Found: C, 44.49; $\mathrm{H}, 4.53 ; \mathrm{N}, 3.01 \%$. IR $\left(\mathrm{KBr}, \mathrm{cm}^{-1}\right): 3421\left(\mathrm{v}_{\mathrm{OH}}\right), 1608$, $1587\left(\mathrm{v}_{\mathrm{C}=\mathrm{N}}\right), 1475,1442,1389\left(\mathrm{v}_{\mathrm{OAc}}\right)$; UV-Vis $\left(\lambda_{\max }\right.$, $\mathrm{nm}): 249,303,367,422 ;{ }^{1} \mathrm{H}$ NMR $(\delta \mathrm{ppm}, 400 \mathrm{Mz}$, DMSO- $\left.d^{6}\right) \delta=8.90(\mathrm{~s}, 1 \mathrm{H}), 7.58(\mathrm{~s}, 1 \mathrm{H}), 6.99-6.40$ (Ar-H, 5H), 4.13-4.09 ( $\mu-\mathrm{OAc}, 3 \mathrm{H}), 3.78\left(-\mathrm{OCH}_{3}, 3 \mathrm{H}\right)$, ppm (figure 1).

\subsection{Physical measurements}

Elemental analyses (carbon, hydrogen and nitrogen) were performed on a Perkin-Elmer 2400 CHNS/O elemental analyser. IR spectra ( $\mathrm{KBr}$ discs, $4000-300 \mathrm{~cm}^{-1}$ ) were recorded using a Perkin-Elmer FT-IR model RX1 spectrometer. Ground-state absorption and steady-state

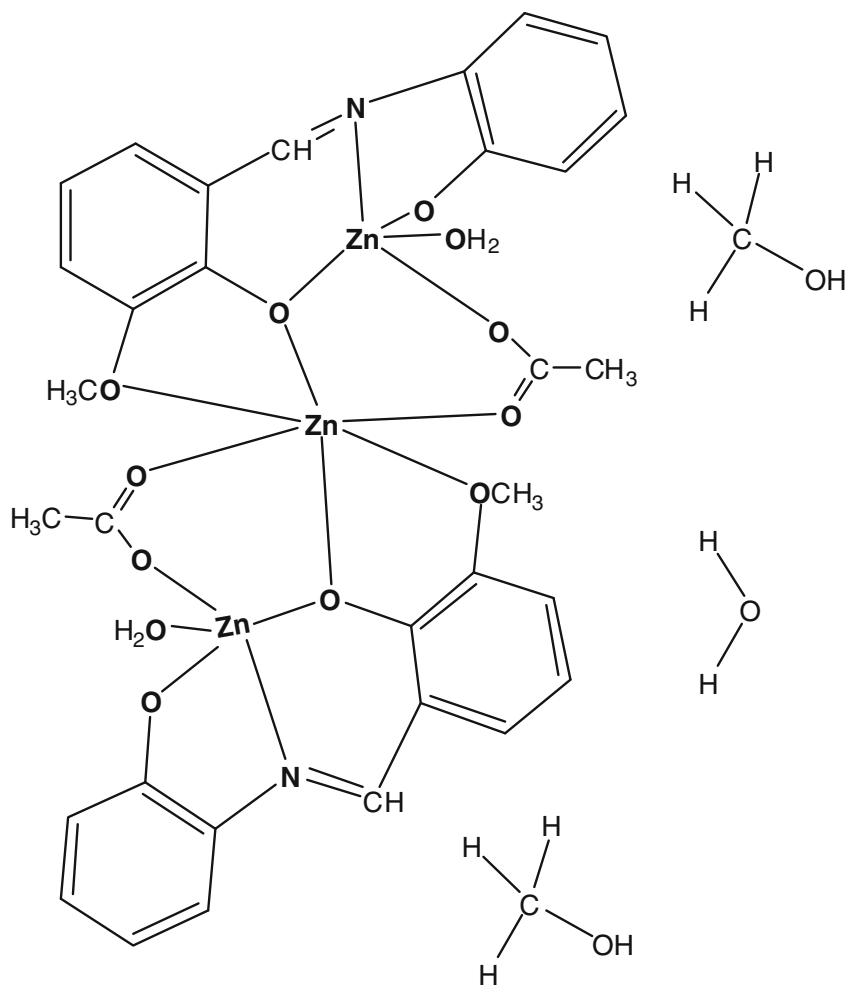

Figure 1. Proposed structure of the trinuclear zinc(II) complex. 
fluorescence measurements were made with a Jasco model V-530 UV-Vis spectrophotometer and Hitachi model F-4010 spectrofluorimeter, respectively. The ${ }^{1} \mathrm{H}$ NMR spectra were recorded on a Bruker AC300 spectrometer. Thermal analysis was done on Perkin-Elmer Diamond TG/DTA system. The crystalline phase was identified by powder X-ray diffraction patterns (XRD) of the materials by using a BRUKER AXS (Model: 8D-ADVANCE) diffractometer with a $\mathrm{Cu} \mathrm{K}_{\alpha}$ radiation source under continuous scanning mode in the range of $8^{\circ}-60^{\circ}$. Electrospray ionization (ESI) mass spectrum was recorded using a Waters Micro Q-TOF Mass Spectrometer.

\subsection{Thermal melting studies}

Absorbance versus temperature profiles (optical melting curves) of DNA and zinc(II) Schiff base complexDNA were measured on the Shimadzu Pharmaspec 1700 unit (Shimadzu Corporation, Kyoto, Japan) equipped with the peltier-controlled TMSPC- 8 model accessory in eight-chambered quartz cuvette of $1 \mathrm{~cm}$ path length. The temperature was ramped from 40$110^{\circ} \mathrm{C}$ at a scan rate of $0.5^{\circ} \mathrm{C} / \mathrm{min}$. monitoring the absorbance changes at $260 \mathrm{~nm}$. $T_{\mathrm{m}}$ is taken as the midpoint of the melting transition as determined by the maxima of the first derivative plots.

\subsection{Viscosity measurements}

For viscosity studies, sonicated DNA of ( $280 \pm 40$ base pairs) was used. Viscosity of the DNA-metal complex was determined by measuring the time needed to flow through a Cannon-Manning semi micro size 75 capillary viscometer (Cannon Instruments Company, State College, PA, USA) that was submerged in a thermostated water bath $\left(20 \pm 1^{\circ} \mathrm{C}\right)$. Small volumes of the solution of $\mathbf{1}$ were added to sonicated CT DNA solution placed in the viscometer. Mixing was effected by slowly bubbling dry nitrogen gas. Flow times were measured in triplicate to an accuracy of $\pm 0.01 \mathrm{~s}$ with an electronic stopwatch Casio Model HS-30W (Casio Computer Co. Ltd., Tokyo, Japan). Relative viscosities for DNA either in the presence or absence of $\mathbf{1}$ were calculated from the relation:

$$
\eta_{\mathrm{sp}}^{\prime} / \eta_{\mathrm{sp}}=\left\{\left(t_{\text {complex }}-t_{\mathrm{o}}\right) / t_{\mathrm{o}}\right\} /\left\{\left(t_{\text {control }}-t_{\mathrm{o}}\right) / t_{\mathrm{o}}\right\},
$$

where $\eta_{\mathrm{sp}}^{\prime}$ and $\eta_{\mathrm{sp}}$ are specific viscosities of the 1-DNA complex and the DNA, respectively; $t_{\text {complex }}, t_{\text {control }}$, and $t_{\mathrm{o}}$ are the average flow times for the DNA-1 complex, free DNA and buffer, respectively.

\subsection{In vitro antimicrobial activity}

Antibacterial activity of the ligand and the complex were tested against the bacterial species Bacillus subtilis, B. megaterium, Staphylococcus aureus, Escherichia coli, Salmonella typhimurium, Pantoea ananetis, Pseudomonas aeruginosa and Pseudomonas fluoresence by Kirby Bauer Disc diffusion method. ${ }^{15}$ The ligand and complex were also tested against the fungal species Penicillium, Cladosporium, Aspergillus parasiticus, Rhizopus, fusarium, Alternaria, Helminthosporium and Colletotrichum, cultured on malt extract agar medium and also performed by the disc diffusion method. The test organisms were grown on nutrient agar medium in petri plates. The disks were soaked with test samples, drained and then placed on the nutrient agar plate using sterilized forceps. The discs were placed on previously seeded plates and incubated at $37^{\circ} \mathrm{C}$ (for bacteria) and $28^{\circ} \mathrm{C}$ (for fungi) and the diameter of inhibition zone ${ }^{15 \mathrm{~b}}$ around each disc was measured after $24 \mathrm{~h}$ for bacteria and $72 \mathrm{~h}$ for fungi. At the end of the incubation period, the zones of inhibition around the disc were measured in $\mathrm{mm}$. On the basis of preliminary tests, the compounds effecting significant zones of inhibition were then selected and used for determination of minimum inhibitory concentration (MIC).

Linear growth of the fungus was obtained by measuring the diameter of the colony on a Petri plate after $72 \mathrm{~h}$ and the percentage of inhibition was calculated from the following relationship:

$$
\% \text { inhibition }=[(C-T) / C] \times 100,
$$

where $C=$ diameter (in $\mathrm{mm})^{2}$ of the fungus colony in the control plates after $72 \mathrm{~h}$ and $T=$ diameter of the fungus colony in the treated plates.

\section{Results and discussion}

\subsection{Synthesis and formulation}

Schiff base ligand $\mathrm{H}_{2} \mathbf{L}$ was synthesized by $1: 1$ condensation of $O$-aminophenol and $O$-vanillin in dehydrated alcohol. 1 was prepared using reaction among $\mathrm{Zn}$ (II) salt and the ligand in methanol. Coordination geometry of 1 was determined by different spectroscopic characterization.

\subsection{Spectroscopic characterization}

3.2a IR characterization: Coordination sites of the Schiff base ligand involved in coordination with the 
metal ion has been examined by careful comparison of the IR spectra of the free ligand and complex. The IR spectrum of the free ligand is characterized mainly by the strong peaks at 3365 and $1618,1595 \mathrm{~cm}^{-1}$ which are attributed to the stretching frequencies of -OH (aromatic) and $\mathrm{C}=\mathrm{N}$ (imine), respectively. The strong bands at 1608 and $1587 \mathrm{~cm}^{-1}$ due to $\mathrm{C}=\mathrm{N}$ stretching in the spectrum of the ligand shifts to lower wave numbers in the zinc complex by $8-15 \mathrm{~cm}^{-1}$ indicating that the imine nitrogen atoms of the Schiff base are coordinated to the metal ion. The band at $3365 \mathrm{~cm}^{-1}$ due to $\mathrm{O}-\mathrm{H}$ (aromatic) in ligand disappears in the complex, thus clearly indicating the coordination of the ligand through the deprotonated $\mathrm{O}-\mathrm{H}$ group. The strong peak at $3420 \mathrm{~cm}^{-1}$ is due to presence of water molecules. The peaks at 1475, 1442 and $1389 \mathrm{~cm}^{-1}$ are assignable to symmetrical stretching frequencies of carboxylate $(-\mathrm{COOH})$ moiety. Further, the IR spectra of the complex of $\mathrm{Zn}$ (II) exhibit new peaks at 1293, $1230 \mathrm{~cm}^{-1}$, indicate the chelation between phenolate-O and zinc(II) ion (figure S1). Characteristic bands in the range of 514$876 \mathrm{~cm}^{-1}$ may be assigned to M-N and M-O stretching modes, respectively. ${ }^{16}$

3.2b UV-visible spectroscopy: The electronic spectra provided good information regarding the arrangements of the ligands around the metal ions. The UVVis spectra for ligand and metal complex show high intensity transitions in the range of 200 to $470 \mathrm{~nm}$. The Schiff base ligand $\mathrm{H}_{2} \mathbf{L}$ shows the characteristic absorption bands at 233, 275, 347 and 461. The bands at 233 and $275 \mathrm{~nm}$ are assigned to $\pi-\pi *$ transition of the $\mathrm{C}=\mathrm{N}$ chromophore, whereas the band at $347 \mathrm{~nm}$ is due to $\mathrm{n}-\pi *$ transition and $461 \mathrm{~nm}$ is for intraligand charge transfer ${ }^{17}$ (figure S2). On complexation, these bands were shifted to lower wavelength region, suggesting the coordination of imine nitrogen and phenolate oxygen with $\mathrm{Zn}(\mathrm{II})$ ion (figure $\mathrm{S} 2$ ). The complex is soluble in common organic solvents.

3.2c ${ }^{1} H$ NMR and mass spectrometric characterization: The NMR spectra of Schiff base and its Zn(II) complex are recorded in dimethylsulphoxide (DMSO$d 6$ ) solution using tetramethylsilane (TMS) as an internal standard. The spectrum of the complex is examined in comparison with the parent Schiff base. Upon examination, it is found that two types of phenolic$\mathrm{OH}$ signal appear in the spectrum of $\mathrm{H}_{2} \mathbf{L}$ ligand at 12.581 and $5.941 \mathrm{ppm}$. The first one indicates aromatic $\mathrm{OH}$ proton in vanillin and the second one indicates the aromatic $\mathrm{OH}$ proton in aminophenol, respectively. The characteristic signal at $8.704 \mathrm{ppm}$ indicates the proton of imine- $\mathrm{CH}$ and all aromatic- $\mathrm{CH}$ proton signals produce in the range of 6.907-7.261 ppm. The proton signal at $3.939 \mathrm{ppm}$ assigns methoxy protons. The signals found in the spectrum of the zinc(II) complex are in the range of $2.086-8.874 \mathrm{ppm}$. There are no signals at 12.581 and $5.941 \mathrm{ppm}$ in the $\mathrm{Zn}$ (II) complex which assigns the deprotonated phenolic-OH groups during chelation with $\mathrm{Zn}$ (II) ion (figure S3). New characteristic signals at 4.09-4.13 are assignable to involvement of the $\mathrm{COOH}$ group in chelation with $\mathrm{Zn}$ (II) ions. The proton signal at $3.76 \mathrm{ppm}$ assigns the participation of methoxy-O in connection with metal ion. The signals at $\sim 2.5$ indicate the presence of coordinated water molecules.

Mass spectral study of this $\mathrm{Zn}$ complex is in good agreement with the theoretical molecular mass of the complex and also the data confirm the trinuclear nature of the $\mathrm{Zn}$ (II) complex. The ESI mass spectrum of $\left[\mathrm{Zn}_{3} \mathbf{L}_{2}\left(\mu-\mathrm{O}_{2} \mathrm{CCH}_{3}\right)_{2}\left(\mathrm{H}_{2} \mathrm{O}\right)_{2}\right] \cdot \mathrm{H}_{2} \mathrm{O} \cdot 2 \mathrm{CH}_{3} \mathrm{OH}$ exhibited three triplets of peak envelopes (figure $\mathrm{S} 4$ ) at $\mathrm{m} / \mathrm{z}$ 306.0, 308.0, 310.0 and 610.9, 612.9, 614.9 and 915.9, 918.0 and 919.9. The molecular ion peak is found at $m / z$ 915.99. The $m / z$ values were very consistent with assignment to the ions. ESI-MS (MeOH) $\mathrm{m} / z 306.2$ $[\mathrm{ZnL}+\mathrm{H}]^{+}$(base peak, calcd. 306.9), $612.9\left[\mathrm{Zn}_{2} \mathbf{L}_{2}+\mathrm{H}\right]^{+}$ (calcd. 612.01), $915.99\left[\left\{\mathrm{Zn}_{3} \mathbf{L}_{2}\left(\mu-\mathrm{O}_{2} \mathrm{CCH}_{3}\right)_{2}\left(\mathrm{H}_{2} \mathrm{O}\right)_{2}\right]\right.$. $\left.\left.\mathrm{H}_{2} \mathrm{O} \cdot 2 \mathrm{CH}_{3} \mathrm{OH}\right\}+\mathrm{H}\right]^{+}$(calc. 916.03).

\subsection{PXRD characterization}

The powder X-ray diffraction (PXRD) pattern of $\left[\mathrm{Zn}_{3} \mathbf{L}_{2}\left(\mu-\mathrm{O}_{2} \mathrm{CCH}_{3}\right)_{2}\left(\mathrm{H}_{2} \mathrm{O}\right)_{2}\right] \cdot \mathrm{H}_{2} \mathrm{O} \cdot 2 \mathrm{CH}_{3} \mathrm{OH}$ is shown in figure 2. All the peaks in the diffraction pattern can be indexed with the triclinic structure with $\mathrm{P}-1$ space group using WINPLOTR programme. The extracting cell parameters are $a=10.71613 \AA, b=12.19746 \AA$,

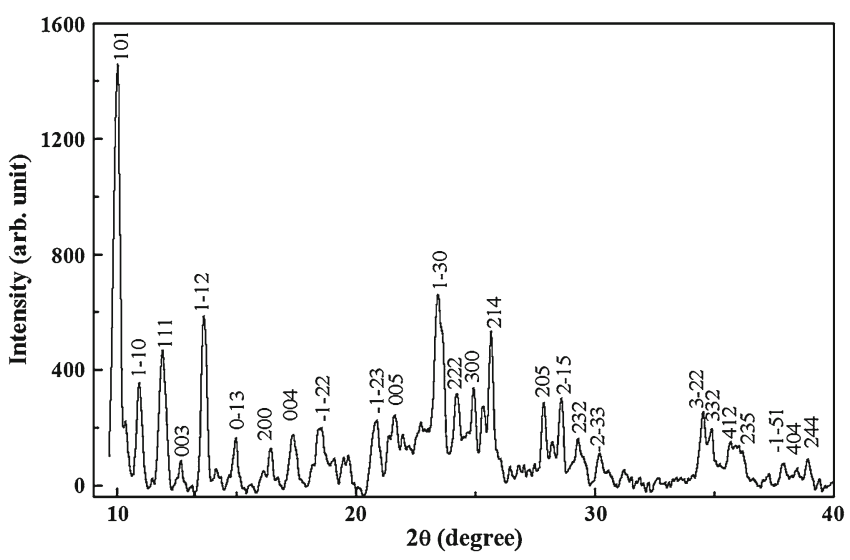

Figure 2. Powder X-ray diffraction patterns along with h, $\mathrm{k}$, 1 values for $\mathrm{Zn}(\mathrm{II})$ complex. 
$c=20.47784 \AA, \alpha=91.43^{\circ}, \beta=91.80^{\circ}, \gamma=90.28^{\circ}$ and the unit cell volume is $2674.440(\AA)^{3}$. From PXRD, it is revealed that the complex is in crystalline phase.

\subsection{Thermogravimetric analysis}

Thermal behaviour of the Zinc(II) cluster was followed up to $800^{\circ} \mathrm{C}$ in a static nitrogen atmosphere with a heating rate of $10^{\circ} \mathrm{C}$ per minute. $\left[\mathrm{Zn}_{3} \mathbf{L}_{2}(\mu\right.$ $\left.\left.\mathrm{O}_{2} \mathrm{CCH}_{3}\right)_{2}\left(\mathrm{H}_{2} \mathrm{O}\right)_{2}\right] \cdot \mathrm{H}_{2} \mathrm{O} \cdot 2 \mathrm{CH}_{3} \mathrm{OH}$ (1) decomposed in four steps (figure S5). The first two steps from $40^{\circ}$ to $297^{\circ} \mathrm{C}$ corresponds to the endothermic process with the loss of solvated methanol, solvated aqua molecule, two coordinated water molecules and bridging acetate molecules with the mass loss of $25.7 \%$ (calcd. 23.8\%). In the next two steps, the coordination environment is decomposed and the experimental mass loss agrees well with calculated mass loss.

\subsection{DNA binding studies}

3.5a Spectrophotometric titration: The DNA-binding experiments were performed in Tris- $\mathrm{HCl}$ buffer (50 mM Tris- $\mathrm{HCl}, \mathrm{pH}$ 8) using a methanol solution of the complex 1. Concentration of CT DNA was determined from the absorption intensity at $260 \mathrm{~nm}$ with an $\varepsilon$ value $^{18}$ of $6600 \mathrm{M}^{-1} \mathrm{~cm}^{-1}$. Absorption titration experiments were made using different concentrations of CT DNA, while keeping the complex concentration constant. Due correction was made for the absorbance of the CT DNA itself. Samples were equilibrated before recording each spectrum. A broad spectrum in the range of $250-500 \mathrm{~nm}$ is shown in the UV-Vis spectrum of the

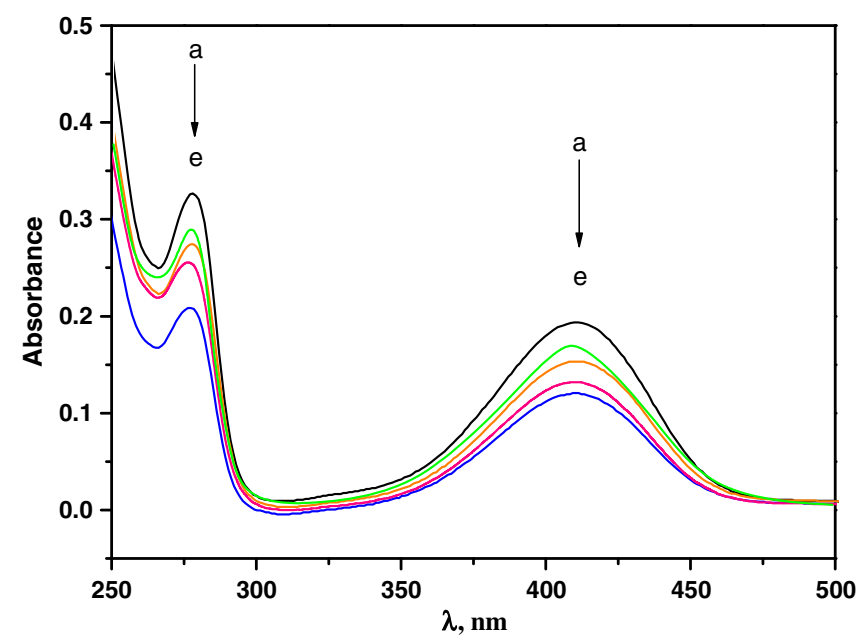

Figure 3. Electronic spectrum of the title complex through titration with CT-DNA in tris- $\mathrm{HCl}$ buffer; the increase of DNA concentration is indicated by an arrow. complex (figure 3). After addition of CT-DNA to the solution of $\mathrm{Zn}(\mathrm{II})$ complex in tris-buffer, it is clearly observed that the absorption peak at $417 \mathrm{~nm}$ undergoes a significant decrease in molecular absorption (hypochromic effect) with no detectable shift in the absorption wave length. The gradual decrease in the absorption wavelength indicates strong interaction of 1 with DNA double strand. The binding constant, $K_{\mathrm{b}}$ for the complex has been determined from the plot of [DNA] $/\left(\varepsilon_{\mathrm{A}}-\varepsilon_{\mathrm{F}}\right)$ vs. [DNA] and found to be $3.11 \times$ $10^{4} \mathrm{M}^{-1}(R=0.9670$ for four points) (figure 4$)$.

3.5b Spectrofluorimetric titration: The fluorescence spectral method using standard intercalator ethidium bromide (EB) as a reference was used to determine the relative DNA-binding properties of the complex to the CT-DNA in tris-buffer ( $5 \mathrm{mM}, \mathrm{pH} 8.0)$. Fluorescence intensities of EB in DNA were measured at different complex concentrations. Addition of the complex to the DNA pretreated with EB causes an appreciable reduction in the fluorescence intensity (figure 5) indicating that 1 competes with EB to bind with DNA. Reduction of the emission intensity gives a measure of the DNAbinding propensity of the complex and stacking interaction (intercalation) between adjacent DNA base pairs. ${ }^{19}$ Relative binding tendency of the complex with the CTDNA was determined from the comparison of the slope of the lines in the fluorescence intensity versus complex concentration plot.

Quenching of EB bound to DNA by the title complex is in agreement with the linear Stern-Volmer equation:

$$
I_{0} / I=1+K_{\mathrm{SV}}[\text { complex }]
$$

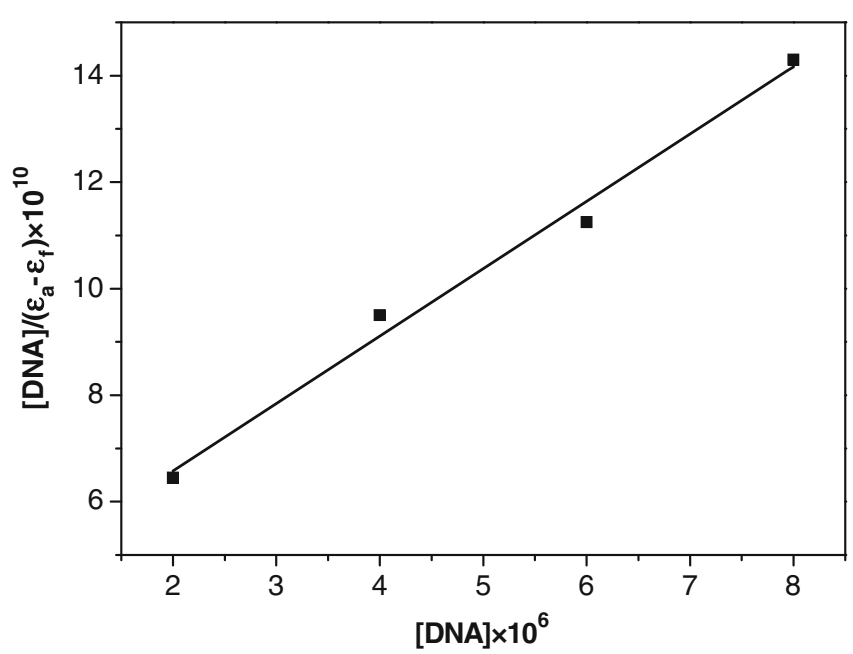

Figure 4. Plot of $[\mathrm{DNA}] /\left(\varepsilon_{\mathrm{A}}-\varepsilon_{\mathrm{F}}\right)$ vs. [DNA] for the titration of CT-DNA with 1 in tris- $\mathrm{HCl}$ buffer, binding constant $K_{\mathrm{b}}=3.11 \times 10^{4} \mathrm{M}^{-1}(R=0.9670$ for four points $)$. 


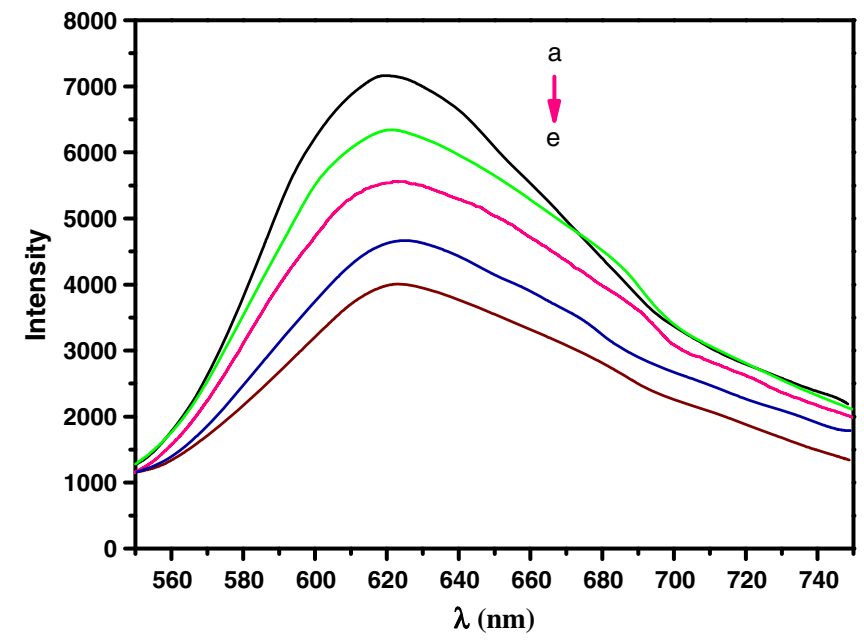

Figure 5. Emission spectra of the CT-DNA-EB system in tris- $\mathrm{HCl}$ buffer based on the titration of $1 . k_{\mathrm{ex}}=524 \mathrm{~nm}$; The arrow indicates the increase of the complex concentration.

where $I_{0}$ and $I$ represent fluorescence intensities in the absence and presence of quencher, respectively. $K_{\mathrm{sv}}$ is the linear Stern-Volmer quenching constant and [complex], the concentration of the quencher. From the slope of the regression line in the derived plot of $I_{0} / I$ versus [complex] (figure 6), the $K_{\mathrm{sv}}$ value for the complex was found to be $3.08 \times 10^{4} ;(R=0.9917$ for four points $)$ indicating a strong affinity of the complex to CT-DNA.

3.5c Thermal melting studies: The binding was further tested from optical thermal melting studies. ${ }^{20}$ Double stranded CT-DNA under the conditions of the

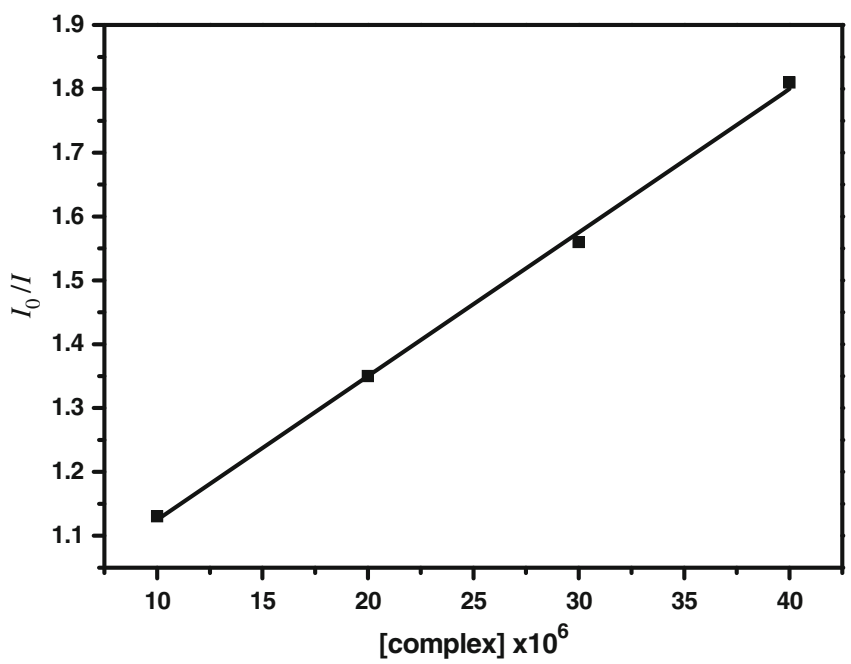

Figure 6. Plot of $I_{0} / I$ vs. [complex] for the titration of CT-DNA-EB system with 1 using spectrofluorimeter; linear Stern-Volmer quenching constant $\left(K_{\mathrm{sv}}\right)$ for $\mathbf{1}=3.08 \times 10^{4}$ ( $R=0.9917$ for four points).

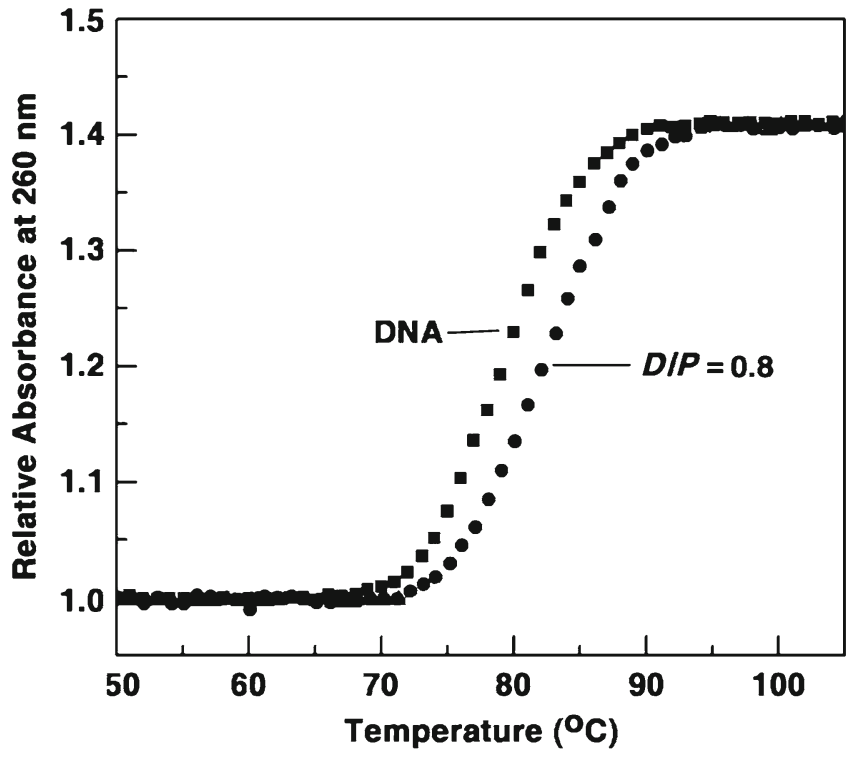

Figure 7. Thermal melting profile (relative absorbance change at $260 \mathrm{~nm}$ versus temperature) of CT DNA $(20 \mu \mathrm{M})$ and its association with $\mathrm{Zn}(\mathrm{II})$ complex.

experiment had a melting temperature $\left(T_{\mathrm{m}}\right)$ of $78^{\circ} \mathrm{C}$ (figure 7). Melting temperature of the native DNA enhanced in the presence of the complex. The $\Delta T_{\mathrm{m}}$ value is $4^{\circ} \mathrm{C}$ when the $D / P$ ratio is 0.8 . Such high stabilization of the DNA helix is essentially due to the strong binding of 1 either in the grooves or by intercalation or by both modes.

3.5d Hydrodynamic studies: To further probe and distinguish between groove-binding, intercalative or partial intercalative and groove-binding modes, viscosity of the DNA solution was measured in the presence

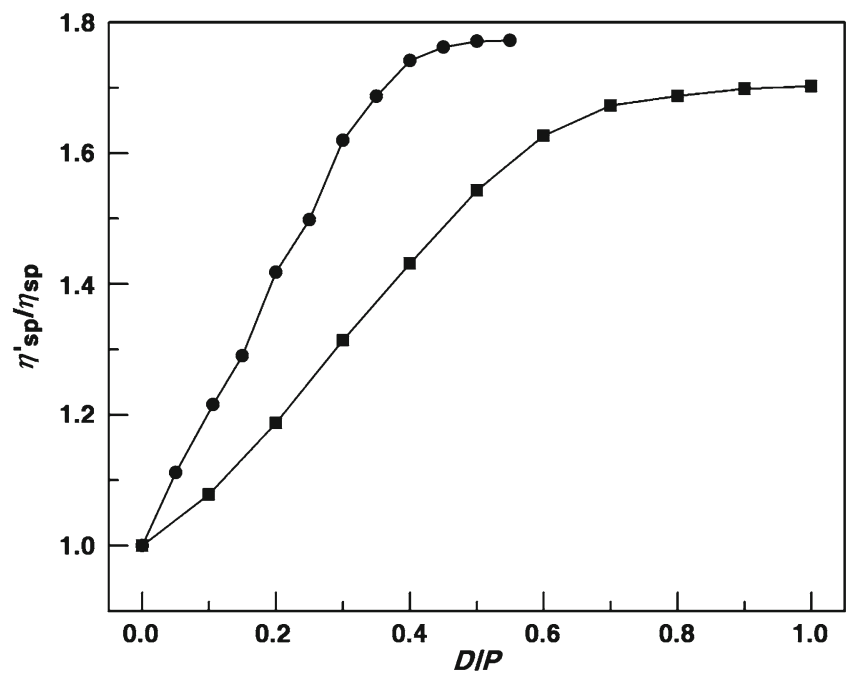

Figure 8. Plot of $\eta_{\mathrm{sp}}^{\prime} / \eta_{\mathrm{sp}}$ versus $D / P \quad[\mathrm{DNA} / \mathrm{EtBr}(\bullet)$, DNA/Zn-complex ( $\square)]$. 
Table 1. Antibacterial activity of Schiff base ligand and its zinc complex.

\begin{tabular}{lccccc}
\hline & \multicolumn{5}{c}{ Zone of inhibition (mm) } \\
\cline { 2 - 6 } Compound & $\begin{array}{c}\text { Escherichia } \\
\text { coli }\end{array}$ & $\begin{array}{c}\text { Salmonella } \\
\text { typhimurium }\end{array}$ & $\begin{array}{c}\text { Pseudomonas } \\
\text { aeruginosa }\end{array}$ & $\begin{array}{c}\text { Staphylococcus } \\
\text { aureus }\end{array}$ & $\begin{array}{c}\text { Bacillus } \\
\text { subtilis }\end{array}$ \\
\hline Methanol (control)* & - & - & - & - & - \\
$\mathrm{H}_{2} \mathbf{L}$ & 7 & 6 & 6 & 5 & 3 \\
$\mathrm{Zn}$ (II)-L complex & 14 & 13 & 15 & 10 & 7 \\
\hline
\end{tabular}

of increasing concentrations of $\mathbf{1}$ and the change in relative viscosities with varying inputs of $\mathbf{1}$ were estimated. ${ }^{21}$ Hydrodynamic method provides unequivocal evidence for the mode of binding. ${ }^{22,23}$ Relative specific viscosity of the CT-DNA-1 complex increased steadily as the $D / P$ (complex/DNA molar ratio) increased and ultimately attained saturation at $D / P \geq 1.0$ (figure 8). A control experiment was also performed with the classical intercalator EB. A comparative study was performed with the classical intercalator EB. Results favour a intercalation mode of binding of the iron complex into the double helical organization of the CT DNA.

\subsection{Bio-assay investigations}

In testing the antibacterial and antifungal activity of these compounds, we used more than one test organism to increase the chance of detecting antibiotic principles in tested materials. A volume of $100 \mu \mathrm{L}$ of microbial suspension was spread onto agar plates corresponding to the broth in which they were maintained. Isolated colonies of each organism that might be playing a pathogenic role should be selected from primary agar plates and tested for susceptibility by disc diffusion method. The ligand and its metal complex have been screened for their antimicrobial activity and the results are presented in tables 1 and 2 .

Enhanced activity of the complex over the Schiff base can be explained on the basis of mechanistic aspects of Tweedy's Chelation theory. ${ }^{24}$ Chelation reduces the polarity of the metal ion considerably, mainly because of the partial sharing of its positive charge with donor groups and possible $\pi$-electron delocalization on the whole chelate ring. The lipid and polysaccharides are some important constituents of cell walls and membranes, which are preferred for metal ion interaction. In addition to this, the cell wall also contains amino phosphates, carbonyl and cysteinyl ligands, which maintain the integrity of the membrane acting as a diffusion barrier and also provides a suitable site for bonding. Chelation can reduce not only the polarity of the metal ion, but also increases the lipophilic character of the chelate, and the interaction between the metal ion and the lipid is favoured. This may lead to breakdown of the permeability barrier of the cell, resulting in interference with the normal cell process.

Schiff base ligands with multifunctionality have a greater chance of interaction either with nucleoside bases (even after complexation with metal ion) or with biologically essential metal ions present in the biosystem can be promising candidates as bactericides since they always tend to interact especially with some enzymatic functional groups, in order to achieve higher coordination numbers. ${ }^{25,26}$ Our zinc(II)-Schiff base complex shows more promising antimicrobial activities (figure S6) than the substituted phenol-based (N,O) donor macrocyclic Schiff base zinc(II) complex. ${ }^{27}$ However, Pushpanathan and Suresh Kumar, ${ }^{27}$ have shown great effect in antimicrobial study by investigation of substituent effect on the macro-cyclic system. The substituent group was strongly deactivating the macro-cyclic system and depleting the electron density inside the ring. As a result, the metal ion became more

Table 2. Antifungal activity of Schiff base ligand and its zinc complex.

\begin{tabular}{lccccc}
\hline & \multicolumn{5}{c}{ Zone of inhibition (mm) } \\
\cline { 2 - 5 } Compound & Penicillium & Cladosporium & $\begin{array}{c}\text { Aspergillus } \\
\text { parasiticus }\end{array}$ & Rhizopus & Helminthosporium \\
\hline mg/0.01 ml & - & - & - & - & - \\
Methanol (control)* & 5 & 5 & 6 & 6 & 4 \\
$\mathrm{H}_{2} \mathbf{L}$ & 9 & 7 & 9 & 10 & 7 \\
$\mathrm{Zn}(\mathrm{II})-\mathbf{L}$ complex & & & & \\
\hline
\end{tabular}


electrophilic to be bound strongly with metal-binding sites in the enzymes of the bacteria. In our case, metalligand coordination reduces the polarity of the metal ion significantly which makes this trinuclear Zn(II) cluster almost non-polar and it is also reflected from the solubility of this complex in various non-polar solvents. Due to enhancement of non-polar character in this zinc cluster, it is probably adsorbed on the surface of the cell wall of microorganisms and disturbs the respiration process of the cell and thus blocks the synthesis of the proteins that restricts further growth of the organisms. So, the trinuclear $\mathrm{Zn}$ (II) cluster behaves as the growth-inhibitor for microorganisms.

\section{Conclusion}

In the present investigation, we have reported synthesis, structural characterization and biological activity of a zinc(II) complex with a Schiff base ligand. Binding constant for the complex is found to be $3.11 \times 10^{4} \mathrm{M}^{-1}$ ( $R=0.9670$ for four points). The linear Stern-Volmer quenching constant was determined as $3.08 \times 10^{4}$; ( $R=0.9917$ for four points). The complex 1 enhanced the thermal stabilization of native DNA by $4^{\circ} \mathrm{C}$ clearly suggesting strong stabilization effects. Viscosity measurements provided evidence for intercalation of $\mathbf{1}$ into the DNA double helix. Overall studies indicate an intercalative mode of binding with the CT-DNA. Biological activities of the Schiff base and the zinc(II) complex against bacterial and fungal organisms are promising which need further extensive studies on animals and humans.

\section{Supplementary information}

The electronic supporting information can be seen in www.ias.ac.in/chemsci.

\section{Acknowledgements}

We thank Dr. C Malla Reddy, IISER, Kolkata, for providing mass spectral studies. Bhaskar Biswas thanks the University Grant Commission, New Delhi, India for financial support.

\section{References}

1. (a) Protivinsky R 1971 Antibiot. Chemother. 17 101; (b) Joshi K C, Pathak V N and S K Jain 1980 Pharmazie 35 677; (c) Sima 2001 J. Croat. Chem. Acta. 74593

2. Shepherd R G 1970 In Medicinal chemistry (ed.) A Burger (New York: Wiley)
3. (a) Sing S P, Shukla S K and Awasthi L P 1983 Curr. Sci. 52 766; (b) Danda A, Kaur V and Singh P 1993 Indian J. Pharm. Sci. 55 129; (c) Ouyang X M, Fei B L, Okamuro T A, Sun W Y, Tang W X and Ueyama N 2002 Chem. Lett. 3362

4. (a) Logan J C, Fox M P, Morgan J H, Makohon A M and Pfau C J 1975 J. Gen. Virol. 28 271; (b) Datta A, Karan N K, Mitra S and Rosair G 2002 Naturforsch. Z. 57b 999; (c) Jayabalakrishnan C and Natarajan K 2002 Trans. Met. Chem. 2775

5. (a) Omar A, Mohsen M E, Nabil H and Hassan M 1984 Arch. Pharm. 317 68; (b) Sharghi H and Nasseri M A 2003 Bull. Chem. Soc. Jpn. 76137

6. (a) Singh D and Singh R V 1993 J. Inorg. Biochem. 15 227; (b) Joseyphus R S and Nair M S 2008 Mycobiology 3693

7. (a) Keene F R, Smith J A and Collins J G 2009 Coord. Chem. Rev. 253 2021; (b) Dhara K, Ratha J, Manassero M, Wang X-Y, Gao S and Banerjee P 2007 J. Inorg. Biochem. 101 95; (c) Uma V, Castineiras A and Nair B U 2007 Polyhedron 26 3008; (d) Kumar P, Garai S, Santra M K, Mondal B and Manna D 2012 Dalton Trans. 41 7573

8. (a) Basu U, Khan I, Hussain A, Kondaiah P and Chakravarty A R 2012 Angew. Chem. Int. Ed. 51 2658; (b) Basu U, Khan I, Koley D, Saha S, Kondaiah P and Chakravarty A R 2012 J. Inorg. Biochem. 11677

9. (a) Nie H, Anbin S M J, Mashuta M S, Porter R A, Richardson J F, Hendrikson D N and Buchanan R M 1996 Inorg. Chem. 35 3325; (b) Vijayalakhmi R, Kanthimathi M, Parthasarathi R and Nair B U 2006 Bioinorg. Med. Chem. 143300

10. Schiff H 1864 Justus Liebigs Ann. Chem. 131 118

11. Biswas B, Mitra M, Adhikary J, Krishna G R, Bag P P, Reddy C M, A-Alcalde N, Chattopadhyay T, Das D and Ghosh R 2013 Polyhedron 53264

12. Biswas B, Hunaiti A A, Räisänen M T, Ansalone S, Leskelä M, Repo T, Chen Y-T, Tsai H-L, Naik A D, Railliet A P, Garcia Y, Ghosh R and Kole N 2012 Eur. J. Inorg. Chem. 4479

13. Biswas B, Pal A, Krishna G R, Reddy C M, Tuna F and Ghosh R 2012 Polyhedron 31671

14. Constable E C, Housecroft C E, Zampese J A and Zhang G 2012 Polyhedron 44150

15. (a) Bauer A W, Kirby W M M, Sherries J C and Truck M 1996 Am. J. Clin. Pathol. 45 493; (b) Bonferoni M C, Rossi S, Ferrari F and Caramella C, 1999 Pharma. Dev. Tech. 445

16. Nakamoto K 2009 Infrared and Raman spectra of inorganic and coordination compounds, Part B: Applications in coordination, organometallic and bioinorganic chemistry (New York: John Wiley \& Sons Inc.) Sixth ed.

17. Sole J G, Bausa L E and Jaque D 2005 An introduction to the optical spectroscopy inorganic solids (New York: John Wiley \& Sons)

18. Reichmann M E, Rice S A, Thomas C A and Doty $\mathrm{P}$ 1954 J. Am. Chem. Soc. 763047

19. Lepecq J B and Paoletti C 1967 J. Mol. Biol. 2787

20. Hossain M and Kumar G S 2009 Mol. BioSyst. 5 1311 
21. Sinha R, Islam M M, Bhadra K, Kumar G S, Banerjee A and Maiti M 2006 Bioorg. Med. Chem. 14800

22. Satyanarayana S, Dabrowiak J C and Chaires J B 1993 Biochemistry 322573

23. (a) Sasmal P K, Patra A K, Nethaji M and Chakravarty A R 2007 Inorg. Chem. 46 11112; (b) Mahadevan S and Palaniandavar M 1998 Inorg. Chem. 37 693; (c) Yang X-B, Huang Y, Zhang J-S, Yuan S-K and Zeng R-Q 2010 Inorg. Chem. Commun. 131421
24. Thimmaiah K N, Lioyd W D and Chandrappa G T 1985 Inorg. Chim. Acta $\mathbf{1 6 0} 81$

25. Levingson W, Mikeleus P, Jackson J and Kaska W 1978 Inorganic and nutritional aspects of cancer (ed.) G N Schranzer (New York: Plenum Press)

26. Manhas B S, Sardana A K and Kalia S B 2005 Syn. React. Inorg. Metal-Org. Nano-Met. Chem. 35171

27. Pushpanathan V and Suresh Kumar D 2013 Int. J. Inorg. Bioinorg. Chem. 335 